\title{
Evaluation of a Caries Detecting Software System
}

\section{Evaluación de un software para la detección de caries}

Jay A. Aldous DDS, MS'; Gary Lowder DDS²; Jerald Boseman DDS³

1. Emeritus Associate Professor, University of Utah School of Dentistry, USA.

2. Associate Professor, Dental Occlusion and TMD, University of Utah School of Dentistry, USA.

3. Associate Professor, Section Head Radiology, University of Utah School of Dentistry, USA.

Correspondence to: Dr. Gary Lowder - gary.lowder@hsc.utah.edu

Received: 16-I-2017

Accepted: 25-V-2017

Published Online First: 29-V-2017

DOl: http://dx.doi.org/10.15517/ijds.v0i0.29161

ABSTRACT

The diagnostic accuracy of caries detecting software that assesses density in digital radiographs was questioned. Analysis of radiographs of extracted teeth using Logicon revealed a deviation in specificity for caries from visual examination of the teeth as well as from their radiographic images. Subsequent preparation of teeth similar to a clinical preparation for a restoration revealed a marked deviation from the Logicon analysis. Radiographic interpretation of early caries and resultant treatment decisions are a multifaceted complex process that is not simplified by desired but unreliable current computerized technique.

\section{KEYWORDS}

Caries detection; Logicon; Diagnosis.

\section{RESUMEN}

La precisión diagnóstica del software de detección de caries que evalúa la densidad en radiografías digitales fue evaluado. El análisis de radiografías de dientes extraídos utilizando Logicon reveló una desviación en la especificidad para la caries con respecto al examen visual de los dientes así como de sus imágenes radiográficas. La preparación subsiguiente de dientes similar a una preparación clínica para una restauración reveló una marcadadesviación del análisis Logicon. La Interpretación radiográfica de caries tempranas y su tratamiento son decisiones con un proceso complejo multifacético, el cual no es simplificado por la técnica computarizada.

\section{PALABRAS CLAVE}

Detección de caries; Logicon; Diagnóstico. 


\section{INTRODUCTION}

Early detection and diagnosis of dental caries has the potential for preservation of natural tooth structure. G. V Black's concept of "extension for prevention" might be logically replaced with "prevention of extension", andas one author has stated, "Were he (Dr. Black) alive today, he would be leading the advance of new technology" (1). Utilizing modern dental restorative materials and techniques for treatment of early cavitated lesions enables the dental professional to effectively eradicate the caries progression process with minimal loss of otherwise healthy adjacent enamel and dentin. However, "The provision of restorative care based on inadequate diagnostic evidence, particularly and imperfect specificity of the diagnostic test, may cause a tremendous amount of overtreatment ..." (2).

The key to effective and successful treatment decisions is accurate diagnosis. The most commonly used method of diagnosing interproximal lesions has been clinician's visual interpretation of dental radiographs, referred to as bitewing $x$-rays. However, studies have preven that there is significant variability in diagnostic accuracy due to several factors including radiographic exposure technique and operator interpretation of the radiograph. With digital radiography, technique issues have improved but there still remains the lack of reliability of the visual interpretation by the operator. Gordon Christensen's CR Clinician Report discusses the evaluation of incipient lesions and reported that none of the radiographic systems tested showed the full extent of progression into dentin of the lesions when compared to actual excavation of those same lesions (3). A more objective method of evaluating and diagnosing lesions is certainly desirable.

"Visually diagnosing radiographs for proximal caries is difficult because of variations in radiographs due to exposure level, tooth structure and tooth shape, and because the eye tends to smooth out shades of gray (4). To date, Logicon ${ }^{\mathrm{TM}}{ }^{*}$ is the only system that is available to detect lesions in teeth by measuring density variations found in images on digital radiographs.

The first report on the use of Logicon cited its ability to find twenty percent more caries penetrating into the dentin than visual radiographic examination without its use (5). The efficacy of this software system has had mixed reviews. Two papers by Wenzel reported Logicon had less accuracy than humans observers (6-7). A report in support of the efficacy of this software system says, "Application of the Logicon program increased the sensitivity, especially in lesions with caries extending into the dentin" (8). A more recent report continues to question the accuracy of the caries detection software and found inconsistent and varied analysis on the caries in a studied surface. The most recent study examining the reliability of Logicon concluded, "LCD (Logicon Caries Detection) appears to be more reliable in ruling out (both enamel and dentin) caries than in detecting caries" (9).

In the directions for the use of Logicon, warnings and precautions indicate that the algorithms "are based on laboratory data for unrestored proximal surfaces of adult dentition. Results for primary dentition, occlusal surfaces or surfaces with existing restorations were not evaluated for safety and effectiveness and could be misleading" (10). Also, radiographs improperly exposed or with overlapping proximal contacts should not be analyzed. These constraints considerably limit the use of this system.

\section{MATERIALS AND METHODS}

To examine the accuracy of Logicon software, extracted teeth were collected from a hospital dental clinic, remaining tissue and calculus were removed from the teeth, and teeth were visually 
examined for signs of caries or cavitation using a sharp explorer. These teeth were $x$-rayed and then examined using Logicon in order to detect changes in radiographic density not visible to the unaided eye. Teeth selected had at least one noncavitated proximal surface that could be examined using $x$-rays recorded on a digital sensor. Teeth were positioned on a protective sleeve on the sensor and stabilized with red carding wax, the buccal surface facing the $x$-ray tube.

Twenty-eight teeth were examined using x-rays recorded on a Kodak RVG 6100 digital sensor, manufactured January 2011, and exposed for six "impulses" from a Gendex"•' GX 770 X-ray machine at a cone to sensor distance of $14.5 \mathrm{~cm}$. Six impulses produced an ideally exposed radiograph. Consistency of cone to sensor distance was maintained with a fixed sensor holding device. Radiographs were visually examined to detect the presence of caries with the results printed on photographic paper using a HP PhotoSmart 8500 printer. The radiographs were then analyzed using Carestream Logicon Caries Detection software 4.0. The radiographic images were stored and analyzed on a Toshiba Satellite laptop computer.

Each tooth was then carefully excavated removing the proximal tooth structure with a diamond bur in a high speed handpiece utilizing water spray to the depth of the recorded caries on the Logicon analysis. The tooth was repeatedly examined visually during the excavation process utilizing Orascopic 3D-2.6. Telescopes to confirm the presence or lack of caries. Signs of caries were indicated by change in the appearance or staining either in the enamel or dentin. Any cavitation or softening of the tooth structure was detected using a sharp dental explorer. This protocol of evaluating caries was used as it simulated closely how a practicing dentist would be evaluating caries in a tooth preparation.

In order to determine if dentin caries was predicated by a change in density in the enamel, eight additional teeth were x-rayed confirming a lack of caries. Then an experimental cavitation was made on the recently extracted, caries free third molars and on one central incisor. A number two round bur was used to penetrate the proximal enamel below the contact point to a depth near the dento-enamel junction. The teeth were again $\mathrm{x}$-rayed and evaluated with Logicon.

To ascertain if dehydration had any influence on the results, three freshly extracted molars were $x$-rayed minutes after extraction, evaluated with Logicon and then left to air dry for three weeks. The teeth were $x$-rayed again and compared with the first evaluation.

\section{RESULTS}

Existence of caries in non-cavitated teeth as indicated by Logicon was compared to visual observation during excavation of the teeth and presented in Table I. None of the surfaces studied on the teeth $\mathrm{x}$-rayed had visible caries or detectable cavitation probed with an explorer. Analysis using Logicon showed caries in the enamel surfaces in all of the 28 teeth previously determined to be without cavitation and caries not present visually on radiographs. With Logicon, twenty of the teeth were diagnosed showing caries extending into the dentin. When the same teeth were excavated, four teeth (samples $14,15,16,22$ ) or $12 \%$ had some indication of a change in the appearance in the enamel but without any breakdown or softening when probed with an explorer. Only one of the excavated teeth studied (\#1) had stain in hard 
dentin at a point different from that indicated by Logicon. This was most likely from caries in the distal occlusal pit in the molar.

When a bur cut into the enamel to simulate cavitation, Logicon approximated the density changes quite accurately in the enamel, but if the bur had penetrated the dentin, the software indicated greater dentin penetration and caries. On the Logicon computer screen, the probability graph anticipated caries beyond the tooth density graph. The results are found in Table 2.

Logicon analysis of the three molars left to air dry for three weeks appeared to have no affect on the Logicon analysis.

Table 1. Logicon Analysis of Non-carious Teeth.

\begin{tabular}{|c|c|c|c|c|c|c|c|c|}
\hline Sample & Tooth\# & $\begin{array}{c}\text { Tooth } \\
\text { Surface } \\
\text { Examined }\end{array}$ & $\begin{array}{c}\text { Visible } \\
\text { Radiographic } \\
\text { Caries }\end{array}$ & $\begin{array}{l}\text { Caries in } \\
\text { Enamei on } \\
\text { Logicon }\end{array}$ & $\begin{array}{l}\text { Caries in } \\
\text { Dentin on } \\
\text { Logicon }\end{array}$ & $\begin{array}{c}\text { Caries } \\
\text { seen after } \\
\text { Section } \\
\text { Enamel }\end{array}$ & $\begin{array}{c}\text { Caries } \\
\text { Seen after } \\
\text { Section } \\
\text { Dentin }\end{array}$ & Cavitation \\
\hline 1 & 2 & $\mathrm{D}$ & No & + & + & - & + & No \\
\hline 2 & 13 & M & No & + & + & - & - & No \\
\hline 3 & 25 & M & No & + & + & - & - & No \\
\hline 4 & 22 & M & No & + & + & - & - & No \\
\hline 5 & 22 & $M$ & No & + & + & - & - & No \\
\hline 6 & 11 & $M$ & No & + & - & - & - & No \\
\hline 7 & 12 & D & No & + & + & - & - & No \\
\hline 8 & 24 & M & No & + & + & - & - & No \\
\hline 9 & 25 & D & No & + & + & - & - & No \\
\hline 10 & 8 & D & No & + & + & - & - & No \\
\hline 11 & 11 & M & No & + & - & - & - & No \\
\hline 12 & 13 & D & No & + & + & - & - & No \\
\hline 13 & 26 & $M$ & No & + & + & a & - & No \\
\hline 14 & 32 & M & No & + & + & + & - & No \\
\hline 15 & 5 & D & No & + & - & + & - & No \\
\hline 16 & 11 & D & No & + & - & + & - & No \\
\hline 17 & 10 & D & No & + & + & - & - & No \\
\hline 18 & 25 & M & No & + & + & - & - & No \\
\hline 19 & 7 & $\mathrm{D}$ & No & + & + & - & - & No \\
\hline 20 & 27 & $M$ & No & + & - & - & - & No \\
\hline 21 & 24 & $D$ & No & + & + & - & - & No \\
\hline 22 & 23 & $M$ & No & + & + & + & - & No \\
\hline 23 & 32 & $D$ & No & + & - & - & - & No \\
\hline 24 & 1 & $\mathrm{D}$ & No & + & - & - & - & No \\
\hline 25 & 1 & $D$ & No & + & - & - & - & No \\
\hline 26 & 16 & $\mathrm{D}$ & No & + & + & - & - & No \\
\hline 27 & 9 & $M$ & No & + & + & - & - & No \\
\hline 28 & 9 & $M$ & No & + & + & $a$ & $a$ & No \\
\hline
\end{tabular}

a: The enamel flaked off during excavation. 
Table 2. Logicon analysis following placement of a bur hole.

\begin{tabular}{llllllll}
\hline Sample & Tooth \# & $\begin{array}{c}\text { Tooth surface } \\
\text { examined }\end{array}$ & $\begin{array}{c}\text { Caries in } \\
\text { Enamel an } \\
\text { Lagican }\end{array}$ & $\begin{array}{c}\text { Caries in } \\
\text { Dentin an } \\
\text { Lagican }\end{array}$ & $\begin{array}{c}\text { Caries in } \\
\text { Enamel after } \\
\text { hale }\end{array}$ & $\begin{array}{c}\text { Caries in } \\
\text { Dentin after } \\
\text { hale }\end{array}$ & $\begin{array}{c}\text { Caries in } \\
\text { Dentin } \\
\text { Predicted } \\
\text { an Lagican }\end{array}$ \\
\hline 1 & 16 & D & - & - & + & - & + \\
2 & 17 & M & - & - & + & - & + \\
3 & 16 & M & - & - & + & + & + \\
4 & 17 & M & - & - & + & - & + \\
4 & 17 & D & - & - & + & - & - \\
5 & 8 & M & - & - & + & - & - \\
6 & 32 & D & - & - & + & - & - \\
7 & 17 & M & - & - & + & - & + \\
\hline
\end{tabular}

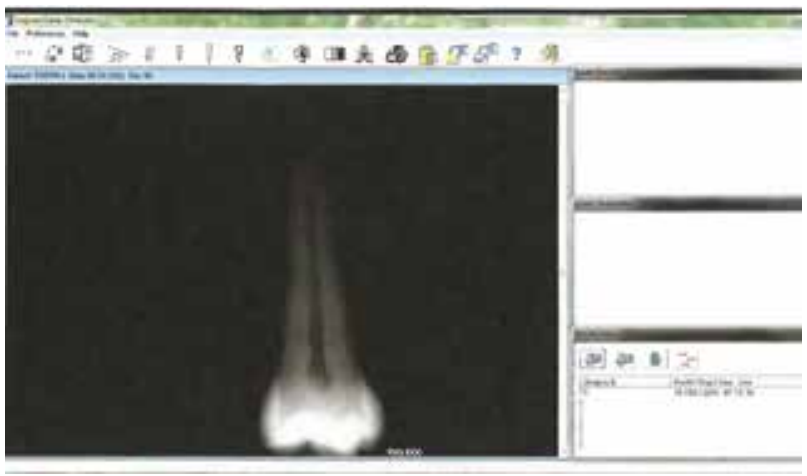

Figure 1. A Digital Radiograph of a Tooth with no Cavitation Before Logicon Evaluation.

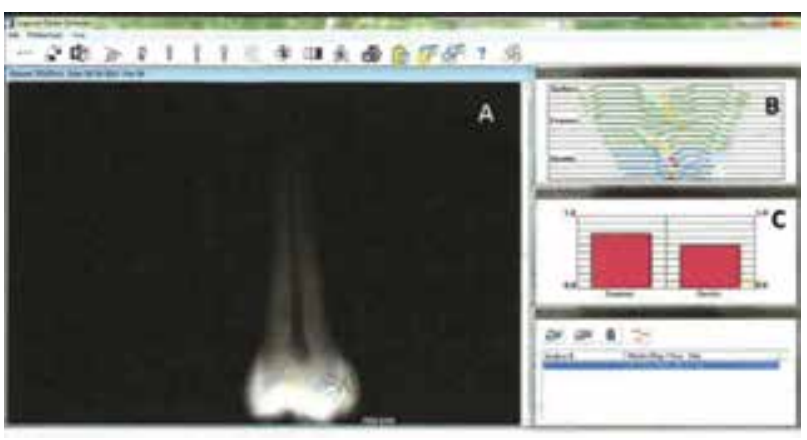

Figure 2. Logicon Evaluation of the Same Digital Radiograph. A. Radiograph showing application of Logicon caries detecting software. Red outline indicates caries in the enamel and dentin. Blue lines indicate the depth of the caries. B. Logicon measured tooth density changes indicating caries (red dots) penetrating through the enamel and into the dentin. C. Lesion Probability. The red column indicates the probability of caries in the enamel and the dentin. The column above the yellow line exceeds the probability of error. 


\section{DISCUSSION}

Preservation of a healthy natural dentition should be the goal of every practicing dentist. The unnecessary or unjustified sacrifice of any portion of tooth structure should be regarded as unethical. The removal of part of a tooth for a restoration should be considered only after careful evaluation of the case. Dentistry in evolving to a minimally invasive approach has been made possible by adhesive restorative materials and greater emphasis on caries prevention. The minimally invasive approach is complex for it requires the evaluation of many factors before tooth restoration: 1 . The evaluation of the patient's caries risk, 2.The presence of cavitation, 3. Evaluation of the extent of a caries process, 4. Evaluation of personal oral hygiene 5 . The potential for remineralization of the lesion and 6.The potential for regular professional follow-up.

The caries process is an infection initiated by bacteria in the biofilm on the surface of the tooth. Bacteria in the biofilm are always metabolically active, causing fluctuations in $\mathrm{pH}$. These fluctuations may cause a loss of mineral from the tooth when the $\mathrm{pH}$ is dropping ora gain of mineral when the $\mathrm{pH}$ is increasing (11). The rate of the progress or recession of caries is determined by the predominant length of time associated with either dissolution or re-deposition of minerals. The potential for remineralization is the important factor that introduces the possibility of preserving tooth structure. The weight of experimental evidence indicates it is bacteria in the biofilm and not in the dentin that promotes progress of caries (12). Potentially a progressing lesion may be arrested if cavitation has not developed.

The presence of cavitation may not be accurately determined radiographically, however, the greater the radiographic depth of the lesion the greater the likelihood of cavitat ion (13).

Because extensive demineralization must occur before the surface breaks down, the percentage of enamel lesions with surface cavitation is small considering the constant biofilm attack. With remineralization, the surface area of the enamel may show an intact radio-opaque layer and a sub surface with more radiolucency (14). Could it be that Logicon is so sensitive, that it interprets a demineralized "scar" with any loss of density as caries and the algorithm extends the caries into the dentin?

Without reliable evidence of cavitation visually or on radiographs, removal of tooth structure for a restoration detected only with software evaluation, is unwarranted destruction of tooth structure and violation of good dental practice. After diagnosing a potential carious lesion, careful assessment of the caries risk for that patient is the critica! treatment consideration. Ideally a dentist should resort to the surgical approach to caries treatment only after evaluation of caries risk and preventive management measures have failed. As Dr. Michael Glick, JADA Editor, says, "Clinical judgment is essential for good decision making" (15). Logicon may indicate areas of impending concern deserving continual follow-up. An unfortunate scenario would be the use of software as the only evaluation to make treatment care decisions rather than asan adjunct to making those decisions.

\section{CONCLUSIONS}

The results of this study suggest that Logicon does not reliably detect caries in enamel and dentin as demonstrated on extracted teeth. The radiographic interpretation of early caries and resultant treatment decisions are a multifaceted 
complex process that is not simplified by desired but unreliable current computerized technique.

\section{REFERENCES}

1. Summitt J. B., Robbins J. W., Hilton T. J., Schwartz R. S., dos Santos J. 3rd ed. Hanover Park, 111: Quintessen Fundamentals of Operative Dentistry: A Contemporary Approach, ce Publishing Co; 2006: VII.

2. Verdonschot E. H., Angmar-Mansson B. Deery C., et al. Developments in caries diagnosis and their relationship to treatment decisions and quality of care. Caries Res.1999; 33 (1): 32-40.

3. Christensen G. J. C. R. Clinicians Report. 2011: 4 (3): 1-3.

4. Gakenheimer D. C. The efficacy of a computerized caries detector in intraoral digital radiography. JADA. 2002; 133(7): 883-890.

5. lbid.

6. Wenzel A. Computer-Automated Cares Detection in Digital Bitewings: Consistency of a Program and 1ts lnfluence on Observer Agreement. Caries Res. 2001; 35 (1): 12-20.

7. Wenzel A., Hintze H., Kokld L. M., Kold S. Accuracy of computer-automated caries detection in digital radiographs compared with human observers. Eur J Oral Sci. 2002; 110 (3): 199-206.
8. Forner-Navarro L., Llena-Puy M. C., Garcia-Godoy F. Diagnostic performance of radioviography in combination with a diagnosis assisting program versus conventional radiography and radioviography in basic mode and with magnification. Med Oral Pato/ Oral Cir Bucal. 2008; 13 (4): E261-5.

9. Behere R. R., Lele S. M. Reliability of Logicon caries detector in the detection and depth assessment of dental caries: An in-vitro study. Indian J Dent Res. 2011; 22: 362-362.

10. Carestream. Logicon Caries Detector Essential Prescribing Information.

11. Kidd EAM, Fejerskov O. What Constitutes Dental Caries? Histophatology of Carious Enamel and Dentin Related to the Action of Cariogenic Biofilms. J Dent Res. 2004; 83 (Spec lss C): C35-C38.

12. lbid.

13. Ratledge D. K., Kidd E. A. M., Beighton D. A Clinical and Microbiological Study of Approximal Carious Lesions. 2001; Caries Res 35 (1): 3-7.

14. White S. C., Pharoah M. J., eds. Oral Radiology, Principies and Interpretation. 6t h Ed. St. Louis,MO: Mosby; 2009: 270-274.

15. Glick M. Clinical judgment, a Requirement far professional identity. JADA. 2011; 142 (12):1333-1334. 